\title{
Obstacles Faced by Apprentice Lawyers in Lower Judiciary: A Case Study on Khulna Judge Court
}

\author{
Hasibul Hossain Sumon* \\ Lecturer, Department of Law, North Western University, Khulna, 236, M. A. Bari Road, Sonadanga, Khulna- \\ 9100, Bangladesh
}

*Corresponding Author: Hasibul Hossain Sumon, Lecturer, Department of Law, North Western University, Khulna, 236, M. A. Bari Road, Sonadanga, Khulna-9100, Bangladesh

\begin{abstract}
Apprenticeship is must to be a lawyer. But this period is very much complex for an apprentice lawyer. Helshe has to pass this period through much hardship. It is heard that sometimes senior lawyers give unwise pressure to apprentices which is not fare. To find out the real situation of apprenticeship I have conducted my research on obstacles faced by apprentice lawyers in Khulna Judge Court. Total 35 legal professionals including 20 apprentice lawyers and 15 practicing lawyers have been interviewed for the purpose of data collection. By surveying among male and female apprentice lawyers I have found various obstacles which are faced by apprentice lawyers. Safety is one of the most burning issues among all obstacles. Sometimes, senior lawyers misbehave with their apprentices. They never think about the career of their apprentices. They only think for their own interest which leads apprentices to darken path. Raising awareness is very necessary for eradicating this problem. To make solution of various problem accountability and transparency should be ensured. After all, senior lawyers should have affection, love and respect to their apprentices. If we become able to solve these problems, a lot of students will come and they will build up their career in this profession.
\end{abstract}

Keywords: Obstacles, Apprentice Lawyers, Court, Khulna

\section{INTRODUCTION}

Legal profession is one of the reputable, humanitarian and unprejudiced professions. Legal practitioners perform their duties honestly and confidently and they use the honorable designation that is "Learned".[1]

Legal profession is an independent profession and legal professionals are regarded as mirror of the society. Earlier students used to take law as their last resort whereas today many choose law as their first priority.

But it is a matter of great sorrow that some legal professionals hardly follow the cannons of professional conduct and etiquette. They sometime misbehave with apprentice lawyers. Even female apprentice lawyers are sexually harassed by their senior lawyers sometime. After completing higher legal education, when apprentice lawyers have faced obstacles in this profession by their senior advocates then their dreams falls down. Beside these they face various obstacles in workplace.

For gaining professional legal qualifications apprenticeship period is very important for every apprentice lawyer. Often it is heard that apprentice lawyers are not warmly welcomed by their senior advocate for apprenticeship. Sometime senior lawyer behaves with apprentice lawyer as a servant. They don't teach them practical legal education spontaneously. Even they do unexpected behavior with apprentice lawyers especially with female lawyers. After working hard with senior lawyers apprentice lawyers get a very little remuneration from their senior lawyers. As a result apprentice lawyer's families don't support this profession. Besides female apprentice lawyers are discouraged by their families because of lack of safety.

As per Bangladesh Bar Council canons of professional conduct and etiquette, it is a duty of an advocate to uphold the dignity and high standing of his profession and his own dignity at all time. And junior and younger member should be respectful to senior and older member should be courteous and helpful towards junior. But it is a matter of sorrow that most of the senior members do not 
welcome an apprentice lawyer cordially. In spite of having Bar Council Canons as a safeguard of apprentice lawyer they feel unsafe.

\section{Materials AND Methods}

\subsection{Study Design}

This research was a comparative study on obstacles faced by apprentice lawyers in lower judiciary. This study was conducted to build awareness among the senior advocates and apprentice lawyers about their rights and duties towards each other.

\subsection{Place of Study}

The study area for this research was Khulna Judge Court.Total 35 legal professionals including 20 apprentice lawyers and 15 practicing lawyers have been interviewed for the purpose of collecting information.

\subsection{Study Period}

The study was conducted during November 2018 to January 2019. During this period standard questionnaire development, data collection, data entry, data analysis and report writing has been completed.

\subsection{Data Collection}

Most of the important material used for the study was a set of interview. For assessment of obstacles faced by apprentice lawyers at present situation a face to face questionnaire interview was carried out among the advocates and apprentice lawyer. Questionnaire was specific and authentic related with their day to day life in legal profession.

\section{ObSTACles of APPRENTICE LAWYERS}

In every profession, obstacles are present. Especially women face more obstacles than men in professional life for our social structure. Legal profession is different than other professions quietly. Legal professionals resolve problems, disputes of human being. It is a matter of sorrow that they also face obstacles in their legal profession. Mainly, new comers of this profession face many problems. By questionnaire survey I have determined some obstacles of apprentice lawyers and I have noticed that male and female apprentice lawyers face different obstacles.

\subsection{Obstacles of Female Apprentice Lawyer}

Equality and non-discrimination between the man and woman are among the primary considerations guiding the enforcement and enjoyment of human rights.[2] Now women play important role in various sectors of our country. But most of the women have no will to come in legal profession for various social obstacles. And those female who are law graduates also have no will to come in legal profession because they face various obstacles in the primary step of legal practice that is apprenticeship. In legal profession men and women are not treated equally in our society.

Even The Constitution of The People's Republic of Bangladesh, 1972 has provided that women shall have equal rights with men in all spheres of the state and of public life.[3] But in practically women never enjoy this.

From the interviews done and studying the existing reports I have got some obstacles of female apprentice lawyers which are given below:

\subsubsection{Gender Biases and Stereotype:}

First of all from the very beginning of her career a female in this profession has to face the fact that she is a 'Female'. Rather than being treated as an apprentice lawyer she is being treated as a 'Female'. This causes a downfall to her confidence and shakes believe she has in herself and her ability.

From the interview I got to know that in case of getting opportunity a male apprentice is given more priority than a female not because of his capability but because of his gender. And the female apprentice can't get close to their seniors like the male apprentice can.So this also becomes a barrier for them.

Female have to face a pre decided thought that as they are female they can't do the things which a male can. Most of the interviewed female apprentice lawyers told me that their senior and male colleagues make them realize that they can't do. Even the senior tries to give them less remuneration. 
Table1. Discrimination on the basis of gender biases and stereotype $(n=35)$

\begin{tabular}{|l|l|l|}
\hline Discrimination on the basis of gender biases and stereotype & \multicolumn{1}{|c|}{ Number } & \multicolumn{1}{|c|}{ Percentage } \\
\hline Yes & 22 & 62.85 \\
\hline No & 15 & 42.86 \\
\hline Total & 35 & 100 \\
\hline
\end{tabular}

\subsubsection{Lack of Family Support}

Every person in this world needs a support to go ahead in his/her life. Family is the sole of that support but through the interview I got to know from apprentice lawyer that their family is not supportive because they don't want their daughter or wife to carry this profession as they have a conception that this profession is not suitable or safe for a woman. In some case apprentices need to work with senior lawyers for a long time even at night. This has become problem especially for female apprentices.

Table2. Lack of family support $(n=12)$

\begin{tabular}{|l|l|l|}
\hline \multicolumn{1}{|c|}{ Lack of family support } & \multicolumn{1}{|c|}{ Number } & \multicolumn{1}{c|}{ Percentage } \\
\hline Yes & 8 & 66.67 \\
\hline No & 4 & 33.33 \\
\hline Total & 12 & 100 \\
\hline
\end{tabular}

\subsubsection{Lack of Favorable Infrastructure}

Maximum female apprentice lawyers said that the court room environment is not women friendly yet and it needs to be improved like there is no proper sanitation system and also no common room facilities.

Only one common room is situated in Khulna Bar Association which is insufficient for female lawyers and apprentices. Unfortunately apprentices are not welcomed in that common room. The sanitation condition is very bad not only for female apprentice lawyers but also for practicing lawyers in Khulna Court. Men and Women lawyers use toilet in almost same place in Bar Association. It is mentioned that senior lawyers' chamber condition is better than court in some cases.

Table3. Lack of favorable infrastructure $(n=15)$

\begin{tabular}{|l|l|l|}
\hline \multicolumn{1}{|c|}{ Lack of favorable infrastructure } & \multicolumn{1}{c|}{ Number } & \multicolumn{1}{c|}{ Percentage } \\
\hline Yes & 12 & 80 \\
\hline No & 3 & 20 \\
\hline Total & 15 & 100 \\
\hline
\end{tabular}

\subsubsection{Sexual Harassment}

Female lawyers face sexual harassment. But these things don't come to light often as women think about their reputation and don't want to come in front. But it happens more in case of apprentice lawyers. I got a story from a female apprentice. She told me that one of her colleagues used to get harassed by a male colleague through messages and when she complained to her senior he got it settled without giving any punishment to him.

The women themselves are not co-operative with each other and don't stand for each other. In fact while taking interviews I heard from many apprentice lawyers that they blame the women for the harassment faced by them. One of the practicing lawyers told in strict words that, "after reaching in this stage, women are also guilty for sexual harassment as they are enough matured."

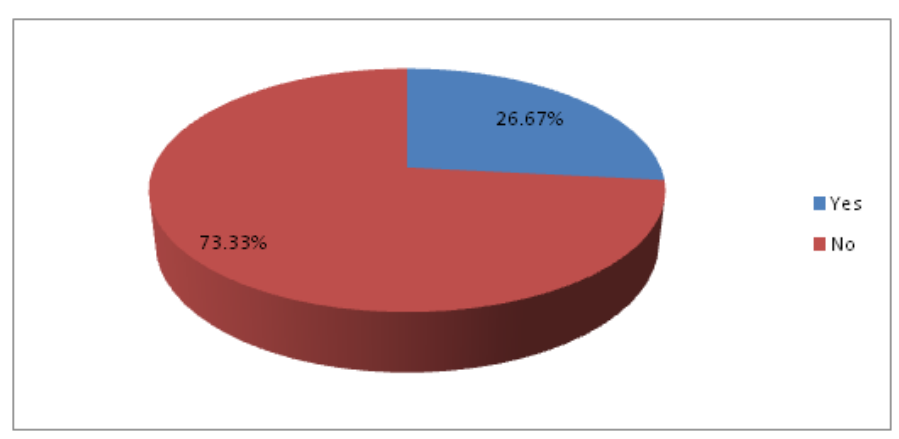

Figure1. Sexual harassment faced by female apprentice lawyer $(n=15)$ 


\subsection{Obstacles of Male Apprentice Lawyers}

Not only female, as well as male also faces many difficulties during their apprenticeship. From the interviews done and studying the existing reports I have got some obstacles of male apprentice lawyers which are given below:

\subsubsection{Financial Problem}

Often it is heard from lawyers that it is easy to become a lawyer but it is difficult to survive economically as young lawyer.[4]

We live in a paternalistic society. Here men are the earning source of all most all family. So they have to work for their family. If they fail to earn enough, his family members have to pass their days through much hardship. But it is a matter of great regret that they get very little for working under a senior lawyer as an apprentice. Sometimes they are paid so little that they can't able to support their transport cost by his remuneration. As a result they take money from his parents after completing his graduation yet. This leads a man to frustration and depression. To get rid of such kind of uncomfortable condition they change their path of career and that's why their cherished dream has remained a dream only.

Table4. Less remuneration getting by apprentice lawyers $(n=35)$

\begin{tabular}{|l|l|l|}
\hline \multicolumn{1}{|c|}{ Less remuneration getting by apprentice lawyers } & \multicolumn{1}{c|}{ Number } & \multicolumn{1}{c|}{ Percentage } \\
\hline Yes & 29 & 82.86 \\
\hline No & 6 & 17.14 \\
\hline Total & 35 & 100 \\
\hline
\end{tabular}

\subsubsection{Ill Treatment}

As an apprentice lawyer has to work under a senior lawyer for learning, they abide by all of the directions of his senior to learn properly. Senior lawyers take this advantage. They treat with apprentice as like as his clerk or servant. They never treat them as their colleague. They involve them in their personal purposes even sometime an apprentice has to go to market to buy his seniors daily necessaries. For this reason an apprentice is discouraged in legal profession and they want to avoid it.

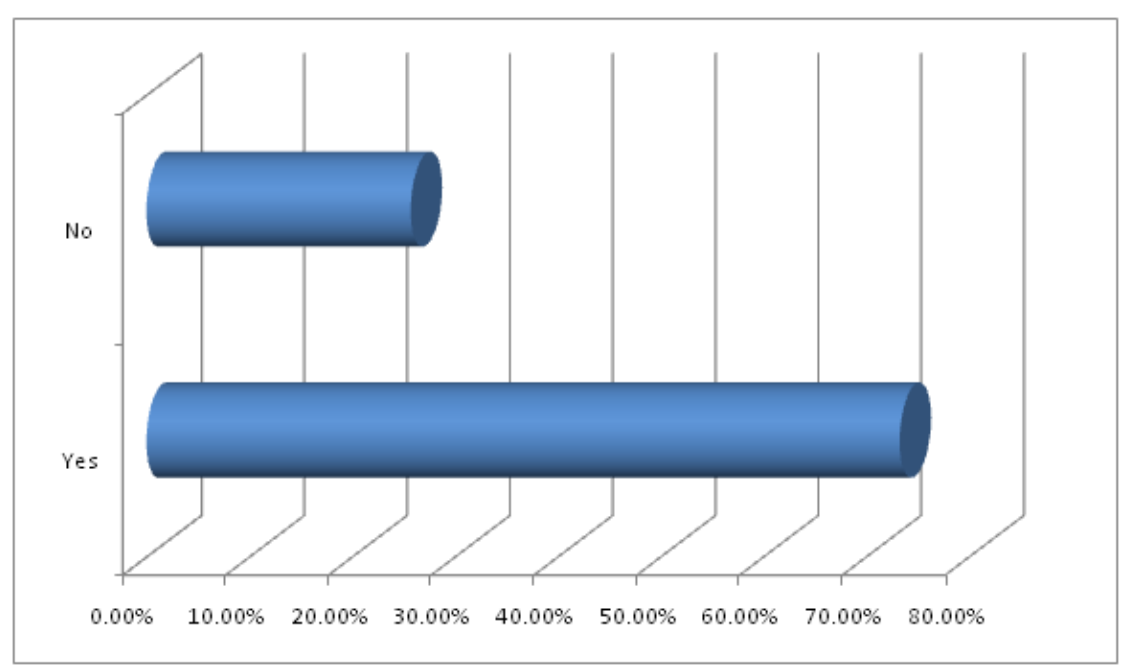

Figure2. ill treatment faced by apprentice lawyer $(n=35)$

\subsubsection{Lack of Affection}

Senior lawyers neglect apprentices. They have no affection to apprentices. Sometimes they treat apprentices as competitor. Besides often they raise question regarding their graduation. They have no tendency to teach them rather they waste valuable time of the career of an apprentice. They want to boss of them and try to give order continuously. But they have no headache for apprentice's learning as well as future.

Most of the obstacles faced by an apprentice are increasing due to the loss of moral values of senior lawyers. They have forgotten their past days when they were an apprentice. Parents do not permit their children for study of law because of maltreatment of the advocates. 


\section{RECOMMENDATIONS}

In all over the world law and justice is one of the mother sectors and legal professionals are appreciated in every country. But some classes of people are subsisting in every society who is backdated in their sense. For these types of people mainly women professionals face barriers and in case of legal profession both male and female face obstacles at the beginning of their career.

After completing law graduation a student enters in difficult world of law profession and at the time of starting professional career he finds himself in strange and cruel world. First of all he has to join a senior lawyer as an apprentice in order to learn necessary skills of this profession. The duration of apprenticeship period varies from few months to long duration.

It is said that there is a solution to every problem. That means every obstacle has way to get rid of it. Being associated with this research for the last few months not only I have learnt about the obstacles of apprentice lawyers but also have got some ways to get rid of them. Some recommendations are given below based on my interviews and study:

\subsection{Practicing Accountability}

There is no accountability of the senior lawyers for what they teach the apprentices. As a result apprentices suffer much. If accountability is practiced properly, apprentices will learn better in their apprenticeship period which will help them in future in his work.

\subsection{Awareness Building Regarding Gender Sensitivity}

It is very essential to create awareness among the females so that they can be conscious about their rights. It is noted that not only female apprentice lawyers suffer gender sensitivity problem but also practicing lawyer face it. Seminars, training programs, leadership programs can be run by the concerned bar association and the private sectors like NGO etc. The civil society can also give their inputs to make the situation even better by sharing their views and making a pathway for others. Educational institution of our country can also arrange seminars, leadership program etc. for building awareness regarding gender sensitivity.

\subsection{Creating Awareness about Sexual Harassment in Court Premises}

Sexual Harassment Committee of bar association should be more active where the female lawyers get remedy as fast as possible. The concerned bar association can arrange counseling sessions for the female victims and there can be a psychiatrist for all the females to boost up their confidence and to help them overcome the obstacles

\subsection{Creating Favorable Atmosphere at Court Premises for Apprentice}

As a student goes for first time in the court, it is a new place for experience for him/her. If the atmosphere is not favorable for him/her then the desire of working will spoil. In this situation nothing good can be expected from his/her. It is very important to establish a favorable atmosphere for a new comer as Law profession is totally different from other profession.

\subsection{Raising Moral Value}

Above all moral values should be raised to solve the obstacles faced by apprentices. To ensure it various steps may be taken by government and other private organizations. It helps people not to go to the unethical path. Without rising of our conscience it is quite impossible to solve these problems.

\section{CONCLUSION}

For the development of judicial sector, the court environment should be made independent, fair and free from discrimination. It is a matter of despond that the court environment is not so. Even here legal professionals especially new apprentice lawyers are faced different types of obstacles. Confronting with so on obstacles some survive in this profession and some has to fall. But if a comfortable environment could have been created for them then we would have got something better from them. And many students will come in this profession spontaneously.

\section{REFERENCES}

[1] www.globalvision24.com/37516/143, accessed on $19^{\text {th }}$ November, 2018

[2] Islam, Md. Zahirul, Basic Essay Composition, $1^{\text {st }}$ Edition, Professor's Prokashon, Dhaka, 2004, p.231 
[3] Haque, ASM Mahmudul, Bangladesher Songbidhan, 3rd Edition, Sufi Prokasoni, Dhaka, 2014, p.46

[4] Difficulties and Problems of Young Lawyers in Pakistan, at http://www.lawsofpakistan.com/difficultiesof-young-lawyers-in-Pakistan, accessed on 2nd January, 2019

\section{AUTHORS' BiOgRAPHY}

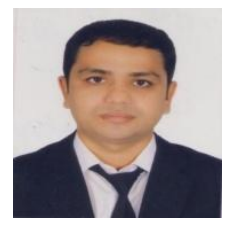

Hasibul Hossain Sumon did his LL.B. (Hon's) and LL.M. from the Department of Law of University of Rajshahi, Rajshahi, Bangladesh. He is now teaching as Lecturer in the Department of Law at North Western University, Khulna, Bangladesh. He is also an advocate (non-practicing) and a member of Dhaka Bar Association, Bangladesh. His interests include both national and international legal issues.

Citation: Hasibul Hossain Sumon. “Obstacles Faced by Apprentice Lawyers in Lower Judiciary: A Case Study on Khulna Judge Court” International Journal of Humanities Social Sciences and Education (IJHSSE), vol 6, no. 2, 2019, pp. 35-40. doi: http://dx.doi.org/10.204 31/2349-0381.0602005.

Copyright: () 2019 Authors. This is an open-access article distributed under the terms of the Creative Commons Attribution License, which permits unrestricted use, distribution, and reproduction in any medium, provided the original author and source are credited. 